\title{
Pattern of Cephalic Index among Medical Students of a Medical College in Eastern Nepal
}

\author{
Raju Kumar Chaudhary, ${ }^{1}$ Sanjib Kumar Sah, ${ }^{1}$ Surya Bahadur Parajuli, ${ }^{2}$ Suman Pokharel, ${ }^{3}$ Santosh \\ Kumar Deo ${ }^{3}$ \\ ${ }^{1}$ Department of Anatomy, ${ }^{2}$ Department of Community Medicine, ${ }^{3}$ Department of Physiology, Birat Medical College \& \\ Teaching Hospital, Tankisinuwari, Morang, Nepal.
}

\begin{abstract}
Background: Cephalic index (CI) is one of the important anthropometric parameter to determine racial variation. Studies done in Nepal has made comparison of cephalic index for castes (Tharu, Brahmin, Chhetri, Newar), races (Mongoloids and Aryans) but lacks sex variation. The objective of this study was to find the difference in the cephalic index between two genders and to find the sequence of most predominant to least common head type in different genders among the Medical Students of Birat Medical College \& Teaching Hospital (BMCTH). Methods: A cross-sectional study conducted in the department of Anatomy of BMCTH from 5 July 2019 to 5 August 2019 comprising of 256 medical students (133 male and 123 female) aged between 18 to 24 years. Head length, head breadth and cephalic index were the variables measured using standard devices and techniques. Ethical clearance taken from Institutional Review Committee (IRC) of Birat Medical College \& Teaching Hospital, Nepal. Results: The mean cephalic index in male and female is found to be $81.41 \pm 4.52$ and $83.62 \pm 4.08$ respectively. Statistically significant difference found between gender in terms of head length males $(18.78 \pm 0.69)$ and females $(17.71 \pm 0.60)$; head breadth males $(15.28 \pm 0.62)$ and females $(14.79 \pm 0.57)$. The mean cephalic index in males is $81.41 \pm 4.52$ varying from 69.31 to 94.48 . In females, the cephalic index varied from 74.74 to 93.14 and the mean cephalic index is $83.62 \pm 4.08$. The difference between male and female cephalic index is found to be statistically significant. Majority (43.75\%) had Brachycephalic head (CI>79.9) followed by Hyperbrachycephalic (26.95\%), Mesocephalic (25.39\%), and Dolicocephalic (3.90\%). Conclusions: Cephalic index is significantly high in female as compared to male whereas head length and breadth are significantly high in males than females. It confirms sexual dimorphism exists. Brachycephalic is the commonest head type.
\end{abstract}

Keywords: anthropometric; brachycephalic head; cephalic index.

\section{INTRODUCTION}

Among different anthropometric parameters used for the determination of racial variations, cephalic index is an important one. ${ }^{1}$ Cephalic index is a ratio of the greatest breath of human head to its greatest length, from front to back, multiplied by 100 . Anthropologists and forensic experts use cephalometry as a tool for identification of racial and sexual variations and comparison of variations between parents, off springs and siblings for the facial reconstruction of disputed identity. ${ }^{1}$ On the basis of cephalic index findings, human skull has been categorized into four head type i.e. dolicocephalic (long headed), brachycephalic (broad headed), mesocephalic (moderate headed) and hyperbrachycephalic (highly broad headed). ${ }^{2}$

The differences in cephalic index specifies regional, racial and gender variations. Studies done in Nepal has made comparison of cephalic index for castes (Tharu, Bhramin, Chhetri, Newar), races (Mongoloids and Aryans) but lacks sex variation. ${ }^{3-7}$ Previous studies lack clarity on the sequence of most predominant head type to least predominant head type in different genders. Therefore, this study was conducted with the objective to find the difference in the cephalic index between two genders and to find the sequence of most predominant to least common head type in different genders among the Medical Students of Birat Medical College \& Teaching Hospital (BMCTH).

\section{METHODS}

This cross-sectional study was conducted from 5 July 2019 to 5 August 2019 in the department of Anatomy of Birat Medical College and Teaching Hospital, Biratnagar, Nepal. The total of 256 medical students (133 males and 123 females) aged between 18 to 24 years (average $=21.16$ years) were included in the study. Ethical clearance was taken from Institutional Review Committee (IRC) of Birat Medical College \& Teaching Hospital, Nepal. A informed consent was obtained from all the participants after providing them detailed information regarding procedure and the benefits of the study. Students with normal cranio-facial skeleton were included and those with any acquired

Correspondence: Raju Kumar Chaudhary, Department of Anatomy, Birat Medical College \& Teaching Hospital, Morang, Nepal. E-mail: rajuanatomist@gmail.com. Phone: +977-9845739363. Article Received: 2019-09-10. Article Accepted: 2019-11-16. 
or congenital cranio-facial deformities of cranial bone, previous history of craniofacial trauma and craniofacial surgery were excluded from this study. Hrdlicka's method was chosen for assessing cephalic index as this method has been used by a number of scientists in their studies. ${ }^{8}$ Spreading caliper, a measuring scale and pencil were used for measurement of head shapes. The participants were asked to sit on a chair comfortably with their head in anatomical position. The maximum head length (MHL) was measured as the greatest anteroposterior diameter from glabella to inion and maximum head-breadth (MHB) was measured as the maximum transverse diameter between two fixed parietal eminences points over the parietal bones. The cephalic index was determined on the basis of international descriptions by Williams et. $\mathrm{al}^{2}$ as shown in Table 1. Cephalic index was calculated using the formula; Cephalic index = Head breadth /Head length x 100 .

\begin{tabular}{|ll|}
\hline $\begin{array}{l}\text { Table 1. Normal range of cephalic index of different } \\
\text { head shapes. }\end{array}$ \\
\hline Head shape & Range of cephalic index \\
Dolicocephalic & $<74.9$ \\
Mesocephalic & $75-79.9$ \\
Brachycephalic & $80-84.9$ \\
Hyperbrachycephalic & $>85$ \\
\hline
\end{tabular}

The descriptive analysis of the data was done to obtain minimum, maximum, mean and standard deviation of head length, head breadth and cephalic index of both sexes. T test was used to compare the means of the variables between males and females. The data were computed and analyzed by using Social Package for Social Sciences (SPSS) 23.0 software.

\section{RESULTS}

Among 256 medical students, 133 were males and 123 are females. The head length, head breadth and cephalic index of all the participants are shown in Table 2.

\begin{tabular}{|llll|}
\hline $\begin{array}{l}\text { Table 2. Head length, Head breadth } \\
\text { index of all the participants. }(\mathbf{n}=\mathbf{2 5 6})\end{array}$ & \\
\hline $\begin{array}{l}\text { Parameters } \\
\text { Mead breadth }\end{array}$ & 13.8 & 16.6 & $15.04 \pm 0.64$ \\
$\begin{array}{l}\text { Headimum } \\
\text { (cms) }\end{array}$ & Maximum & Mean \pm SD \\
$\begin{array}{l}\text { Head length } \\
\text { (cms) }\end{array}$ & 16.1 & 20.6 & $18.27 \pm 0.84$ \\
Cephalic index & 69.31 & 94.48 & $82.48 \pm 4.44$ \\
\hline
\end{tabular}

The gender wise separation of head length, head breadth and cephalic index and its association is shown in Table 3. In males, the mean head breadth was $15.28 \pm 0.62 \mathrm{~cm}$ and the head breadth varies from $14 \mathrm{~cm}$ to $16.5 \mathrm{~cm}$. In females, the head breadth varies from $13.8 \mathrm{~cm}$ to $16.6 \mathrm{~cm}$, the mean head breadth being $14.79 \pm 0.57 \mathrm{~cm}$. The difference between male and female head breadth was found to be statistically significant. Similarly, in males,

\begin{tabular}{|c|c|c|c|c|c|}
\hline \multicolumn{6}{|c|}{$\begin{array}{l}\text { Table 3. Head length, breath and cephalic index of } \\
\text { male and female participants. }(n=256)\end{array}$} \\
\hline Parameters & Gender & Min. & Max. & $\begin{array}{l}\text { Mean } \\
\pm \text { SD }\end{array}$ & p-value \\
\hline \multirow{2}{*}{$\begin{array}{l}\text { Head } \\
\text { breadth } \\
(\mathrm{cms})\end{array}$} & Male & 14 & 16.5 & $\begin{array}{l}15.28 \\
\pm 0.62\end{array}$ & \multirow[t]{2}{*}{$<0.001 *$} \\
\hline & Female & 13.8 & 16.6 & $\begin{array}{l}14.79 \\
\pm 0.57\end{array}$ & \\
\hline \multirow[t]{2}{*}{$\begin{array}{l}\text { Head length } \\
(\mathrm{cms})\end{array}$} & Male & 16.1 & 20.6 & $\begin{array}{l}18.78 \pm \\
0.69\end{array}$ & \multirow[t]{2}{*}{$<0.001 *$} \\
\hline & Female & 16.4 & 19.47 & $\begin{array}{l}17.71 \\
\pm 0.60\end{array}$ & \\
\hline \multirow[t]{2}{*}{$\begin{array}{l}\text { Cephalic } \\
\text { index }\end{array}$} & Male & 69.31 & 94.48 & $\begin{array}{l}81.41 \\
\pm 4.52\end{array}$ & \multirow[t]{2}{*}{$<0.001 *$} \\
\hline & Female & 74.74 & 93.14 & $\begin{array}{l}83.62 \\
\pm 4.08\end{array}$ & \\
\hline
\end{tabular}

the mean head length was $18.78 \pm 0.69 \mathrm{~cm}$ and the head length varies from $16.1 \mathrm{~cm}$ to $20.6 \mathrm{~cm}$. In females, the head length varied from $16.4 \mathrm{~cm}$ to $19.47 \mathrm{~cm}$, the mean head length being $17.71 \pm$ $0.60 \mathrm{~cm}$. The difference between male and female head length was also found to be statistically significant.

The mean cephalic index in males was $81.41 \pm 4.52$ varying from 69.31 to 94.48 . In females, the cephalic index varied from 74.74 to 93.14 and the mean cephalic index was $83.62 \pm 4.08$. The difference between male and female cephalic index was found to be statistically significant. The types of different types of head based on cephalic index are shown in Table 4.

\begin{tabular}{|c|c|c|c|}
\hline \multicolumn{4}{|c|}{$\begin{array}{l}\text { Table } 4 . \quad \text { Different } \\
\text { participants. }(n=256)\end{array}$} \\
\hline Head type & Male & Female & Total \\
\hline Dolicocephalic & $9(6.77 \%)$ & $1(0.81)$ & $10(3.90 \%)$ \\
\hline Mesocephalic & $44(33.08 \%)$ & $21(17.07 \%)$ & $65(25.39 \%)$ \\
\hline Brachycephalic & $51(38.34 \%)$ & $61(49.59 \%)$ & $112(43.75 \%)$ \\
\hline $\begin{array}{l}\text { Hyperbrachyce- } \\
\text { phalic }\end{array}$ & $29(21 \%)$ & $40(35.77 \%)$ & $69(26.95 \%)$ \\
\hline Total & $133(100 \%)$ & $123(100 \%)$ & $256(100 \%)$ \\
\hline
\end{tabular}

This finding suggests that the majority of both males and females participants belonged to Brachycephalic head type. The second predominant head type in male is found to be mesocephalic while that in female is hyperbrachycephalic head type. Dolicocephalic head type is less common head type in both male and female.

\section{DISCUSSION}

Variations in cephalic indices between and within populations have been attributed to a complex interaction between genetic and environmental factors. ${ }^{9,10} \mathrm{We}$ found in a variety of literature that a number of concepts have been followed in studies correlated to cephalic index. Several researchers were interested in comparing several anthropological factors with intelligence ${ }^{11}$ where as some were comparing the data of newer generations with older generations ${ }^{12}$ and also some were comparing the indices in different groups and ethnicity in similar country. ${ }^{1}$ However, in our 
study, we attempted to estimate and study the cephalic indices and head types of the medical students of Birat Medical College and Teaching Hospital, Biratnagar, Nepal.

In our study, we found that the mean cephalic index is $82.48 \pm 4.44$ which belonged to brachycephalic head shape type. The predominant type of head shape in both sex in our study is brachycephalic $(43.75 \%)$ followed by hyperbrachycephalic $(26.95 \%)$, mesocephalic $(25.39 \%)$ and dolicocephalic $(3.90 \%)$. Similar kind of finding was reported in another study carried out in medical students of Nepalese population where the mean cephalic index was 82.04. ${ }^{5}$ Manandhar et al., carried out a similar kind of study in medical students of Nepal and found the mean cephalic index as $81.24 \pm 5.48$ which was similar to our findings. However, in a study done by Pandey et al. in Nepalese medical students, mean cephalic index was found to be $75.82 \pm 4.43$ which was quite lesser than ours finding. ${ }^{6}$

Mean cephalic index of males in our study is 81.41 \pm 4.52 and we came across some literatures having similar findings of cephalic index in male which supported our results. In the study carried out by Timsina et al. in Nepalese male population, cephalic index was found to be $80.88 .{ }^{5}$ Similarly, Manandhar et al., in her study done in Nepalese medical students reported that mean cephalic index of male was $80.51 \pm 5.26$ which was similar to our results whereas Pandey et al. in her study reported the same index to be $75.82 \pm 4.43$ which was lesser than ours. ${ }^{6}$

We found out that the most head shape of male participants in our study is of brachycephalic type (38.34\%) followed by mesocephalic (33.08\%) and hyperbrachycephalic (21\%). Similar finding was shown in study done in gurung community of Nepal $(\mathrm{CI}=83.1 \pm 6.08) .{ }^{7}$ Kumari et al., ${ }^{13}$ Anjankar et al., ${ }^{14}$ Seema and Verma, ${ }^{15}$ and Shah and Jadhav, ${ }^{1}$ also reported that brachycephalic head type is the most commonest head shape found in male in their study done in various Indian population with mean cephalic index value as $80.21,81.24,84.32$ and 80.42 respectively. Similar to our findings predominant head types was brachycephalic in Indian male population (33\%) and Turkman $(42.4 \%) .{ }^{16}$ In contrast to our results, Timsina in his study showed predominant type of head was mesocephalic $(55.76 \%)$ in males. ${ }^{5}$ The dolicocephalic head $(6.77 \%)$ was a rare head types in our study. Similar finding was reported by

\section{REFERENCES}

1. Shah GV and Jadhav HR. The Study of Cephalic index in Students of Gujarat. J. Anat. Soc. India. 2004; 53 (1): 25-6.
Timsina et al. where they found such head type in $1.09 \%$ in Nepalese population. ${ }^{5}$

The cephalic index mean value of female is found to be $83.62 \pm 4.08$ in our study. Timsina et al., conducted study in Nepalese female population showed similar findings where he reported cephalic index value as $83.38 .{ }^{5}$ Manandhar ${ }^{3}$ also reported quite similar findings $(\mathrm{CI}=81.51 \pm 5.62)$ as our results however, Pandey ${ }^{6}$ reported lesser cephalic index in female as $78.36 \pm 5.06$.

The mean cephalic index of female showed that maximum participants $(49.59 \%)$ have brachycephalic head type in our study which is supported by the study done by Timsina et al. who showed the same kind of results in $42.68 \% .{ }^{5} \mathrm{~A}$ study done in Gurung community of Nepal also showed the maximum of brachycephalic head type in their population $(\mathrm{CI}=84.6 \pm 5.14){ }^{7} \mathrm{In}$ contrast to our study result, Pandey ${ }^{6}$ showed that dolichocephalic was predominant in her study done in Nepalese females $(\mathrm{CI}=78.36)$. Our study is however supported by the study done by Shah \& Jadhav $^{1}$, Yagain V K et al., ${ }^{17}$ Vairabhav Anjankar et al. ${ }^{14}$ and Seema \& Verma P. ${ }^{15}$ in various Indian population who reported that the predominant head type in their study population was brachycephalic type.

\section{CONCLUSIONS}

Cephalic index is significantly high in female as compared to male whereas head length and breadth are significantly high in males than females. It confirms sexual dimorphism exists. Brachycephalic is the commonest head type in both genders. A large community based study including more sociodemographic variables will be suggested to find the epidemiological variation in our setting.

\section{Limitations of the Study}

We were not able to consider age and race factor with different morphometric parameters.

\section{ACKNOWLEDGEMENT}

The authors would like to acknowledge the research participants and department laboratory staffs.

\section{Financial Disclosure}

The authors would like to declare that no financial assistance was provided for this study.

\section{Conflict of Interest}

Authors declare no conflict of interest.

2. Williams PL, Bannister LH, Berry MM, Collins P, Dyson M, Dussek JE, et al. Gray's Anatomy. Skeletal system. 38th ed. London, Elbs with Churchill Livingston; 1995. 607-12. 
3. Bipana Manandhar.Cephalic Index among Nepalese Medical Students, Orthodontic Journal of Nepal. 2017;7 (2):20-23.

4. Sanzida Khatun. Cephalic Indigenous Tharu Community, J Nepal Med Assoc. 2018;56(213): 825-29. DOI: $10.31729 /$ jnma.3487

5. Timsina R P, Gogoi P. Anthropometric study of cephalic index among medical students in Nepal. J of Kathmandu Med college.2014; 3(2): 68-71.

6. Pandey N, Jha CB, Yadav G, Sah SK, Yadav P, Awasthi J. Study of Cephalic Index in Nepalese medical students. Int J Anat Res. 2016; 4(4): 3253-56. DOI: http://dx.doi.org/10.16965/ ijar.2016.453

7. Lobo SW, Chandrashekhar TS, Kumar S. Cephalic index of Gurung community of NepalAn anthrpometric study. KUMJ. 2005;3 (11):263-5.

8. Hrdlicka A, Stewart TD. Hrdlicka's Practical anthropometry. 4th edition, Philadelphia:Wistar Institute of Anatomy and Biology; 1952. p. 879.

9. Kasai K, Richards LC and Brown T. Comparative study of craniofacial morphology in Japanese and Australian aboriginal population. Hum Biol 1993; 65(5:) 821 - 34 .

10. Susanne C, Sharma PD, Multivariate analysis of head measurements in Punjabi families. Ann Hum Biol. 1978; 5 (2): 179 - 83.
11. Hirsch NDM. Cephalic index of American born children of three foreign groups. Am J Physical Anthropol. 1927; 10(1):79-90.

12. Tomljanovic AB, Ristic S, Milic BB, Ostojic S, Gombac E, Kapovic M. Secular change in body height and cephalic index of Croatian Medical Students (University of Rijeka). Am J Physical Anthropol. 2004;123:91-6.

13. K. Lakshmi Kumari, P.V.S.S. Vijaya Babu, P. Kusuma Kumari, M.Nagamani. A study of cephali index and facial index in Visakhapatnam, Andhra Pradesh, India. Int J Res Med Sci. 2015; 3(3):656-658. DOI: 10.5455/2320-6012.ijrms20150324

14. Vairabhav P. Anjankar, Shema K Nair, Sandeep singh, Maninder Bindra, D.K. Satpathy. The study of Cephalic Index of Medical Students of Central India. Asian Journal of Biomedical and Pharmaceutical Sciences. 2014; 04 (28):48-50.

15. Seema, Poonam Verma. The Study of Cephalic Index in North Indian Population Int. J. Morphol. 2016; 34(2):660-664.

16. Golalipour MJ, Jahanshahi M, Haidari K. Morphological evaluation of head in Turkman males in Gorgan-North of Iran. Int. J. Morphol. 2007; 25(1):99-102.

17. Yagain VK, Pai S, Kalthur SG,Chethan P, Hemalatha I. Study of cephalic index in Indian students. Int J Morphol. 2012; 30(1):125-9.

Citation: Chaudhary RK, Sah SK, Parajuli SB, Pokharel S, Deo SK. Pattern of Cephalic Index among Medical Students of a Medical College in Eastern Nepal. JCMS Nepal. 2019; 15(4):256-9. 